\title{
How do children and their families experience food poverty according to UK newspaper media 2006-2015?
}

\section{Journal of Poverty and Social Justice}

\section{Authors:}

Abigail Knight, Julia Brannen, Rebecca O’Connell and Laura Hamilton

Thomas Coram Research Unit, UCL Institute of Education, University College London 27-28 Woburn Square, London WC1H 0AA. 0206126948

\begin{abstract}
This paper contributes to scholarship concerned with media representations of poverty by exploring newspaper coverage of food poverty as experienced by UK children and families. Our content analysis of six contrasting print newspapers from 2006-15 finds that reporting of children's and families' food poverty begins in 2011, peaks in 2014 and is dominated by articles about food banks. Narrative analysis identifies differences as well as similarities in the ways the problem is constructed in papers with different political stances as well as notable absences in the coverage, including the broader dimensions of food poverty and the views of children themselves.
\end{abstract}

\section{Keywords:}

Children, families, food poverty, media, newspapers

\section{Introduction}

The language and discourses used by the media to refer to people living in constrained circumstances in the context of neo-liberalism and austerity measures introduced by the UK Coalition and Conservative Governments since 2010 have received much attention by academics in recent years (eg. McEnhill and Byrne, 2014; Jensen, 2014), many writing in this journal. As many of these analyses have shown, the media, particularly the right-wing press, reflects a dominant discourse and ideology that people living in poverty are to blame for their plight, and that many are 'scroungers', 'sponging' off the state, 'frauds', unwilling to work 
and making the 'wrong choices' (Baillie, 2011; Chase and Walker, 2015; Patrick, 2016). It is argued that such discourses perpetuate a mythical narrative linking family dysfunction, worklessness and welfare dependency (Garrett, 2015) and the 'othering' of people living in poverty (Lister, 2004; Krumer-Nevo and Benjamin, 2010; Chauhan and Foster, 2014).

Much of the British media and its owners exercise national and global power and reflect powerful dominant interests (Jones, 2015). As demonstrated by Harkins and Lugo-Ocando (2016) in their study of poverty in UK news reports in the period 1985-2014, much of the British media serve to legitimise inequality through both the discourses they articulate and the rhetorical strategies and narratives they employ. The discursive practices of the news media, they argue, emphasise the inadequacies of individuals thereby dismissing the structural social inequality underlying poverty. They also found, however, that reports about poverty and inequality were more likely to appear in left-leaning newspapers such as The Guardian and The Mirror, emphasising the importance of studying a range of newspapers and the varying discourses they reflect.

This previous research on the relationship between poverty, social inequality and the media suggests the key role played by the UK media in amplifying and shaping policy discourses and public attitudes towards poverty (McKendrick et al, 2008). Our paper seeks to add to these analyses by considering the media attention given to one key aspect of living in poverty: the effect of constrained economic circumstances on food and eating practices and what has been termed 'food poverty' or 'food insecurity'. 'Food poverty' or 'insecurity'i signify 'the inability to consume an adequate quality or sufficient quantity of food in socially acceptable ways, or the uncertainty that one will be able to do so' (Dowler et al, 2001:12). Reflecting this definition, and in line with a general shift in understanding poverty as multidimensional (Hick, 2012), our study, 'Families and Food in Hard Times', conceptualises food poverty as comprising not only lack of food or nutrition but incorporating exclusion, due to a lack of resources, from social participatory aspects of eating. Such a broad definition includes the psychological or emotional condition of worry and uncertainty, and also the issues of 'social acceptability' and 'social participation', i.e. cultural norms which are central to the concept of 'relative poverty' (Townsend, 1979).

There is a long history of research about food and poverty in the UK (eg. Pember Reeves, 1913; Dowler et al, 2001; Lambie Mumford et al., 2014) and rising levels of food poverty 
have been well documented in both academic and policy circles. More recently, research and media coverage have been dominated by a focus on food banks. In part, this is because of the steep rise in the number since the year 2000, when there was only one food bank reported (Wells and Caraher, 2014) in contrast to the year between 2014 and 2015, when over one million people accessed a Trussell Trust foodbank (Garthwaite, 2016). The Trussell Trust Foodbank Network (the UK's largest food bank organisation) has been a key provider of data in the absence of other systematic evidence about levels of household food insecurity. Qualitative research has also been concerned to examine the experiences of food bank users, including the embarrassment and stigma felt by those needing to use the provision (Garthwaite, 2016: Purdam et al, 2016).

In parallel with academic research, there has been a proliferation of media coverage of food poverty in both online and print newspapers and television programmes such as Dispatches: Breadline Kids (Channel 4, 2014). Yet, as Wells and Caraher's $(2014 ; 2016)$ analysis of the media coverage of food banks between 2006 and 2014 showed, although reporting on food banks has become commonplace in the UK press, most coverage has lacked critical analysis. Indeed, the authors suggest, only a minority of newspaper articles question the need for food banks or of the different models for delivering food aid.

Whilst analysis of empirical data from the Trussell Trust by Lambie-Mumford and Green (2017) shows that food banks are playing an increasing role in providing food for children as a result of recent social policy changes, children's experiences of food bank usage, or food poverty more broadly, have received less attention. Furthermore, whilst rights-based approaches to food poverty in the UK and international contexts have been examined by Dowler and Connor (2011) and Riches and Silvasti (2014) among others, food poverty as a rights issue for children and teenagers has received scant research attention (see Kontorravdis et al., 2016 for an exception).

From the few existing studies about children's and families' experiences of food poverty, we know that some parents (particularly mothers) skip meals at times to protect their children from going without and that some children also skip meals or report going to bed hungry (Ridge, 2009; McKendrick, 2003; GLA/Ipsos MORI, 2013). In addition, for many families on low incomes, it is difficult to have friends back to the house for a meal (Ridge, 2002; 2009; McKendrick, 2003), and some children, particularly those who receive free school 
meals, experience 'holiday hunger' when they are not receiving a meal at school (Owen and Sharma, 2004; Machin, 2016). More recent research has shown how welfare benefit changes implemented since the Coalition and Conservative Governments from 2010 have led to some families finding themselves unable to afford adequate food (eg. Cooper et al, 2014; APPG, 2014).

In what follows, we explain the main aims and objectives of the paper and the media analysis on which the paper draws. We present our research questions and the approach we adopted to selecting and analysing the newspapers. We then describe our findings regarding how food poverty for children and families has been covered and constructed in UK newspapers in 2006-2015, focussing our more detailed analysis on 2014-15 - the peak years of coverage of the issue and when the wider research project began. The discussion considers how the media coverage during this period, with some notable exceptions, focuses largely on the rise in the provision of food aid by food banks and key reports about food poverty from government and non-governmental organisations. We also highlight a number of notable absences in the media coverage, such as children's experiences of (food) poverty and children's right to food and the multi-dimensional aspects of food poverty, for example, those related to social exclusionary aspects of food and eating.

\section{Aims and objectives of the paper}

The aim of this paper is to contribute to recent academic analyses and literature examining media discourses about poverty, and about food poverty, by exploring the UK newspaper coverage of food poverty, as experienced by children and families during the period 20062015. This period was identified to chart the rise in media coverage of food poverty for children and families before and after the global financial crisis of 2007-8, the Coalition and Conservative Governments of 2010 onwards and the associated austerity agenda as well as the fluctuating food prices across these years. Our questions for this article focus on how the coverage of food poverty for children and families has been framed in the UK print media, how it has changed over time and how, if at all, its representation differs between left-leaning and right-leaning newspapers.

The study from which this paper draws is a five year (2014-2019) European Research Council funded study of food poverty in the UK, Portugal and Norway, called 'Families and 
Food in Hard Times'. It is a cross-national study with a mixed methods embedded case study design. Phase one (2014-2016) involved the secondary analysis of national and international data, policy and media analyses and Phase two (2015-2017) employed qualitative interviews and other methods with 135 11-15 year olds and their parent/s or carer/s, (45 in each of the three countries). Overall, the study aims to address the question of how social contexts and social positionings mediate the extent and experience of food poverty. This paper draws on some of the work carried out in Phase One, which is the UK media analysis.

In the paper, we identify and explore the discursive context around food poverty as experienced by children and families during 2006-2015. We decided to focus on print newspaper media because time constraints precluded the team from analysing media formats such as TV documentaries. Moreover, despite falls in the circulation of newspapers and the rise in news through online and social media platforms, such as twitter, print newspapers continue to play an important role in providing news to the public. Recent research shows, for example, that the average amount of time spent reading newspapers in print is much higher than the average time spent reading newspapers online (Thurman and Fletcher, 2017).

The paper addresses the following particular research questions, which we developed to provide a useful context for the main study and after examining previous newspaper analyses carried out on topics such as poverty (Chauhan and Foster, 2014) and food bank use (Wells and Caraher, 2014)

a) when did food poverty among children and families in Britain first appear in national newspapers?

b) what was the level of reporting of food poverty among children and families in print media between 2006-2015 and when were the peak years?

c) which key actors, events and themes feature in print media reports?

d) how is food poverty discursively represented and constructed in the newspapers studied?

\section{Research methods and analysis}

\section{Selection of newspapers and articles}

Six newspapers were selected for this analysis, based on their contrasting format, styles and readerships. Although the political persuasion of newspaper media tends to shift over time 
and particularly around general elections, we chose newspapers which were contrasting in their broad political stance: The Daily Mail, (right), The Mirror (left), The Telegraph (right leaning), The Independent (centre left), The Guardian (centre left) and The Times (centreright) and their online and Sunday versions where they existed: MailOnline, The Mail on Sunday (right), The Sunday Mirror (left), The Observer (centre left) and The Sunday Times (centre right) (Wring and Ward, 2010; Chase and Walker, 2015).

We searched the online media database LexisNexis using the combination of the search terms 'food poverty', 'family' and 'child'. We found 935 articles from this search and two researchers from the team independently checked them for relevance using the inclusion and exclusion criteria in Figure 1:

\section{Figure 1 here}

We discussed any discrepancies and saved the articles as Word documents. Using these inclusion and exclusion criteria, we found 313 articles that were relevant to UK food poverty, in the context of family or children.

\section{Stages of Analysis}

Our analysis involved three main phases:

1) Content analysis: we carried out a content analysis on the articles found from 20062015. This approach quantifies the content of text in a systematic manner (Krippendorf, 2013). We recorded the numbers of articles, both relevant and nonrelevant to the topic of food poverty as experienced by children and families during the years in question.We also quantitatively recorded the coverage of child and family food poverty by newspaper type.

2) Thematic analysis of articles 2006-2015: in line with thematic analysis methods (Braun and Clarke, 2006), we identified common themes relating to food poverty as experienced by children and families across all the relevant articles in $2006-2015$. We did this by reading all 313 articles and noting broad themes across them to give us an overview of the food poverty debate and the topics that dominated the reporting during that period. The research team read through the articles independently to 
address the research questions in more detail, in particular to identify the key actors in the debates, the significance of food banks, whether or how children and families featured in the articles and whether and how the tone of the debate and reporting changed over time. This close reading resulted in the generation of common themes and sub-themes and was systematically recorded on a coding frame (Altheide and Schneider, 2013);

3) Narrative analysis of articles 2014-15: we then carried out a narrative analysis of the 175 articles we found in 2014 and 2015, chosen because they included one peak year in the coverage of food poverty, 2014, and the most recent year in our analysis, 2015. A narrative approach is used to interpret texts that have a storied form, by which is meant the sequential, temporal and structural aspects of accounts and reports (Riessman, 2008). The approach prompted us to see beyond the surface of the text and to pay close attention to the language and discourse used to report the topic of food poverty for children and families. We discussed these aspects of the stories together as a research team, and identified case examples of the discursive ways in which food poverty for children and families were represented. For example, when analysing detailed news items and opinion pieces, such as by Wynne Jones (2014b), Styles (2014) and Rayner (2015), which we present later in this paper, we took account of the way in which the story was told, its tone, structure and the specific vocabulary used, to assess the contrasting ways in which food poverty for children and families was being reported and explained.

\section{Research Findings}

\section{The appearance of food poverty among children and families in UK newspapers}

The first stage of the analysis was to identify the number of articles relating to food poverty for children and families between 2006 and 2015. We found 935 from our search terms and, after using our inclusion and exclusion criteria (Figure 1), identified 313 relevant articles (Figure 2). We found that the number of relevant articles rose steeply from 2011, in which there were eight, and peaked in 2014, when there were 124 articles (Figure 3). Of the 313 relevant articles identified between 2006 and 2015, the largest proportion (33\% n=104) were from centre-left broadsheets The Guardian and The Observer (Figure 4). 
Figures 2, 3 and 4 here

\section{The key events and actors in reporting of food poverty among children and families}

Based on our initial thematic analysis of newspapers from 2006-2015, we found that the majority of articles and reports were 'reactive', written in response to a specific event, TV programme or policy/research report. In particular, the announcement of the All Party Parliamentary Inquiry's into Hunger and Food Poverty in February 2014, and its subsequent report Feeding Britain, launched at the end of 2014, produced an avalanche of articles, about 20 per cent of the total articles in 2014 , on food poverty during that year. Other main topics during 2014 concerned the rise in food banks and food bank usage, food waste, the role of the Church in raising awareness of food poverty, various national campaigns such as ClearAPlate ${ }^{\mathrm{ii}}$ and End Hunger Fast, and discussions of food poverty resulting from TV reality programmes such as 'Famous, Rich and Hungry' and 'Breadline Kids'. In 2015, food banks continued to dominate the debate, followed by articles about the link between benefit sanctions and food poverty, a Fabian report on food poverty, Hungry for Change (The Fabian Society, 2014), and the growing concern about 'school holiday hunger' (All Party Parliamentary Inquiry into Hunger in the UK, 2014). Other important topics reported included the rise of fuel poverty as well as the advent of the 'social supermarket'.

Over the decade, articles about food poverty were also dominated by a number of key actors and organisations. These included a) journalists who took up the reports and events and wrote opinion articles about food in the context of low income, such as Patrick Butler (The Guardian) and Ros Wynne Jones (The Mirror), b) government ministers who played an important role in welfare changes that have contributed to food poverty, notably Iain Duncan Smith, Conservative Member of Parliament and Secretary of State for Work and Pensions between 2010 and 2016; Frank Field, Labour MP and Chair of the All Party Parliamentary Inquiry into Hunger and Food Poverty; c) anti-food poverty campaigners working from personal experience such as Jack Monroe d) church leaders, such as the Archbishop of Canterbury, Justin Welby and e) other public figures emphasising individual responsibility for food poverty. One notable example of the latter was the Conservative peer Baroness 
Jenkin, who, following the launch of the All Party Parliamentary Report on Hunger and Food Poverty (of which she was a panel member), declared that the "poor do not know how to cook" adding "I had a large bowl of porridge today, which cost 4p" (quoted in several articles, eg. Wright, 2014).

\section{The place of food banks in newspaper coverage}

Our initial thematic analysis of the articles for the period 2006-2015 found that newspaper coverage of food poverty was dominated by the rising number of food banks. Some coverage relates to the reasons behind their growth. Initially, towards the end of 2011 and into 2012, the food bank rise was largely attributed to economic difficulties relating to recession, income stagnation and increasing food prices. However, as the UK started to move out of recession, media coverage shifted to debates about whether the rise in food banks could be attributed to benefit changes or whether the supply of food banks was fuelling demand. Frequent mentions in 2013 focussed on how the Government (Iain Duncan Smith, sometimes called IDS, in particular) had accused The Trussell Trust of 'scaremongering' about food poverty, refused to meet the organisation and denied its link to benefit sanctions (eg. Helm, 2013).

We focussed our in-depth discursive analysis on the years 2014-15. This included an analysis of two contrasting articles on food banks published 5 days apart in 2014, illustrating the differences in the debate (Figure 5).

\section{Figure 5 here}

Both articles use case examples of food bank users, but the stories are reported in starkly contrasting ways. In the first place, the cases are chosen and presented very differently. The case in The Mirror article is of a woman with serious health problems, including cancer, who was deemed fit for work and 'couldn't make ends meet', an example which is used to help engender sympathy and perhaps anger in the reader. In contrast, the Daily Mail article focuses on a food bank user in a TV documentary called 'Britain's Hidden Hungry', who was 'considered to be the most deserving recipient' but was, in fact, a 'conman'. Such an example, and others including Latvian 'heroin addicts' arriving at a food bank by taxi, are clearly chosen to cast doubt on the needs and motives of food bank users. 
The ways in which the articles refer to evidence and the broader context also differ. While The Mirror draws links between food poverty and inequality by referring to a recent report by Oxfam and the enormous wealth held by the UK's five richest families, The Daily Mail describes the food poverty debate as 'fuelled by questionable and inflammatory statistics'. Actors are also selected and evaluated differently in support of the stories. The Mirror refers to the 'Bishops from the Church of England and other faith leaders' as signatories to the Mirror's petition 'to end the scandal of food poverty'. However, The Daily Mail accuses the bishops of being 'culpable of misleadingly quoting figures' and cites the leader of the Oxford Food Bank, Robin Aitken, to support the view that the supply of food banks has fuelled demand: 'ten years ago there were no food banks, but if you provide a service, people will use it'. The articles thus reflect and reproduce the papers' political stance and particular views of food poverty; in the case of The Mirror, a social problem focus is adopted drawing attention to welfare cuts and issues that need campaigning against; The Daily Mail article constructs food bank use as fuelled by supply and as taken up fraudulently.

With reports in the media in 2014 that food bank usage in the UK had reached a million and of new food banks opening in hospitals and for young people, several articles reported concerns about food banks creating 'welfare dependency' but also that people's over-reliance on them could lead to malnutrition, as a result of the poor-quality food (mainly tinned and packaged) provided. Following the launch of the All Party Parliamentary Inquiry's 2014 report Feeding Britain, the tone of the public debate emanating from Government and reflected in the newspaper coverage of food poverty appears to change, from perceiving food banks as fuelling demand for food aid to becoming a potential new arm of the welfare state. Instead of being seen as an 'enemy', the food bank movement began to be seen as a potential 'partner' (Butler, 2015), in the increasingly mixed economy of welfare in neo-liberal Britain and an example of the 'Big Society'. This was reflected in the new policy directive of placing Job Centre staff in food banks that emanated from the Department of Work and Pensions under Ian Duncan Smith (IDS), who had previously denied the suggestion that food poverty was being caused partly by benefit sanctions. This shift was picked up by Patrick Butler in The Guardian (2015):

' 'Food bank job centres': will DWP make charity handouts part of welfare state? Iain Duncan Smith's move to put jobcentre staff in food banks suggests a shift in outlook - and is tacit admission of link between welfare policy and food poverty' 
And similarly, in The Mirror, Beattie (2015) also emphasised IDS's change in direction:

'IDS says job advisers will be posted in food banks; Last week the PM said he didn't want anyone reliant on food banks. Now Iain Duncan Smith wants to station job advisers in them'.

Perhaps not surprisingly, the shift in debate was not reported in the more right-wing newspapers analysed in 2014-15, such as The Daily Mail or The Telegraph (or if it was, it did not come up in our search).

\section{The presence or absence of children in newspapers?}

Although our search centred on food poverty as experienced by children and families, the number of articles which represented the direct views or experiences of parents and children themselves was strikingly small. Of the 175 articles we analysed closely in the years 2014-15, only seven (4\%) included case examples or discussion relating to a child or a young person; case studies featuring adults were more frequent but still used in a minority of articles, Four of the seven articles about children were related to a Channel 4 Dispatches TV documentary aired in June 2014 called 'Breadline Kids', which presented the experiences of food poverty of a small number of children and their families. These four articles were from The Mirror, which ran two articles (Mayall, 2014; Wynne Jones 2014b), MailOnline (Styles, 2014) and The Guardian (Williams, 2014a). Mayall's article is a direct report of the programme, describing the children portrayed in the programme and their circumstances and he quotes directly from the children, such as "hunger is like "something is biting you" said 10-year-old Cara'.

Below we discuss two contrasting approaches to the reporting of children's experiences of food poverty, as depicted in the programme, Breadline Kids, illustrated in Figure 6.

Figure 6 here

Wynne Jones' writing is characteristic of The Mirror's left-wing stance. It goes beyond reporting the programme (she also uses case studies and direct quotes from the children) linking the documentary's findings with the All Party Parliamentary Inquiry into Food Poverty and Hunger (launched in April 2014, two months previously) and a joint report 
released that week from Oxfam, Church Action on Poverty and the Trussell Trust (Cooper et al, 2014) showing a huge increase in food bank use. She uses hard-hitting critical language such as 'the economy is desperately failing ordinary people, the welfare net has been ripped apart' and the 'food system has also gone obscenely wrong'.

The MailOnline article (Styles, 2014) takes a different approach: the journalist focuses on one young person depicted in the documentary. Although the young person's experience of food poverty and visit to the local food bank are mentioned, it is her artwork and 'inspiring' aspirations to 'break the cycle' to 'make sure I have a decent future for myself and my own family' which are the focus of the piece, suggesting that food poverty is an individual issue that can be overcome through aspiration and responsibility.

Zoe Williams, a regular columnist in The Guardian (Williams, 2014a), was by contrast, very critical of the documentary calling it 'like a horror movie' where 'empathy is like fear'. Although she exclaims that 'poverty is more easily told through the eyes of a child', our analysis showed that, perhaps surprisingly, this is actually rarely done. Although Williams is clearly very critical of what she sees as the exploitative use of the direct experiences of children by the media, she produced a very strongly worded piece later in the same year in The Guardian (Williams, 2014b) arguing for children's right to food. Here she cites the United Nations Convention on the Rights of the Child 1989 (which the UK ratified in 1991) Articles 26 and 27 that state the children have the 'right to benefit from social security' and have a 'right to a standard of living adequate to their physical, social and mental development' which, Williams exclaims, should include the 'right not to be hungry'.

The two other articles that used children's experiences and voices in their reports of food poverty during the period of in-depth analysis included one by Wynne Jones (2015) in The Mirror reporting on the rise of school holiday hunger and another in The Observer (Rayner, 2015), a piece on the services, including food provision, offered by the now defunct charity Kids Company. Reminiscent of Oliver Twist, Wynne Jones starts her article with a description of a church hall in Norwich where a 7-year-old girl is 'clearing her plate' and asks for a second dessert; the day before, she says, she had a 'margarine sandwich' for lunch. The pathos is then linked to evidence of rising food poverty in Britain and the particular challenges families face during the school holidays (Kellogg's/YouGov, 2015; Machin, 2016). Rayner's piece similarly starts with some quotations from children at the Kids 
Company, saying that they 'sometimes miss breakfast' and how one child's 'belly was hurting' because she had no food until lunchtime that day. The article, at 1,948 words, is longer than most and describes in detail the charity and its work with children, focusing on the topic of food in particular. Both articles are illustrative of the common stylistic methods journalists use to grab the attention of the reader through their use of pathos and case examples, to engender a sense of shock as well as empathy.

\section{Discussion and conclusions}

We set out to examine how newspaper media reported children's and families' food poverty of articles using the search terms 'food poverty, family and child' from six contrasting newspapers over the 10-year period 2006-2015. The analysis rarely met our expectations; we found that the vast majority of articles simply reported a piece of news (such as the release of statistics documenting the rise in food bank use or the findings of a new report about food poverty) and in this way re-contextualised (Bernstein, 2000) the press releases provided to newspapers and the original texts such as summaries of official reports. Although their styles (eg. language, length of the piece) varied according to whether it was a broadsheet or a tabloid, in many articles, no particular stance was put forward. Because of the release of statistics about the huge increase in food banks from 2012 onwards and the release of several official reports in 2014 (eg. Cooper et al, 2014; Lambie-Mumford et al, 2014; All Party Parliamentary Inquiry into Hunger, 2014; The Fabian Society, 2014) providing evidence that changes to the benefit system (sanctions in particular) were to blame for the increase, there was a general shift in the coverage from debates about the general causes of rising numbers of food banks to an acknowledgement of the Government's specific contribution through its welfare policies.

However, there were exceptions to this, some examples of which have been highlighted in this article. Feature articles written by key journalists (eg. Patrick Butler/Zoe Williams in The Guardian, Wynne Jones in The Mirror, Rachel Johnson/Richard Littlejohn/Steve Bird in the Daily Mail) tend to reflect a newspaper's political stance. However, they were exceptions rather than the rule. Baroness Jenkin's comments (in December 2014 at the time of the release of the All Party Parliamentary Report, Feeding Britain) about the poor not knowing how to cook, created a furore and media storm, evident in eight articles over two days in December 2014, that quoted her words directly. This perhaps reflects a view that individual 
shortcomings for food poverty were not to blame for its rise. Further, this leads us to suggest that whilst 'poverty' and welfare dependency are seen by most of the newspaper media as an individual failing (Jensen, 2014), food poverty as hunger is seen in a generally more sympathetic light, a failing of society and a Government that permits anyone in $21^{\text {st }}$ century Britain to go without food. Speaking at a conference in 2014, the Guardian journalist Patrick Butler similarly suggested that food poverty may resonate with the public in such a way as to facilitate empathetic media coverage and public understanding of poverty more broadly (Butler, 2014). It has been suggested that a 'halo effect' surrounds food bank users, who are often portrayed by the media as deserving and affected by matters out of their control (Wells and Caraher 2016).

Our analysis also found that the vast majority of articles, from all political perspectives, were related to food banks in one way or another: whether to report the rise in food bank users, to question their need and reasons for existence (benefit reform or supply fuelling demand), the rise in malnutrition due to the poor food provided, the need for an All Party Parliamentary Inquiry, the lobbying of Government by the Church, Oxfam and other concerned parties, the attempts by The Daily Mail to discredit food bank users, the introduction of job advisers to the poor and so on. It is perhaps not surprising that the food bank has beome 'the' face of, or metonym for, food poverty. However, this trope for food poverty denies the multi-faceted experience of living in constrained circumstances that affect food and eating. There is indeed evidence that many people who are food insecure do not use food banks (Purdham et al, 2015).

Furthermore, articles reporting and depicting the experiences of families with children living in food poverty (whether or not they use food banks) are largely absent. Therefore, the hidden experiences of children and families living in food poverty, including those who manage to get by without recourse to food banks, perhaps by turning to friends and family or who live in ever-increasing debt, are, by and large, not taken up by the newspaper media. This resonates with previous research by Kendrick et al (2008) and Wells and Caraher (2014; 2016) who found an absence in the media of the voices of people living in poverty/food poverty and that of Chauhan and Foster (2014), who argue that people living in poverty are othered through representational absence and denial. In regard to the absence of children's voices and experiences more specifically, our findings echo Alderson's notion that children are 'missing' from mainstream debate (2013; 2016). Furthermore, Benson and Rosen (2017) 
suggest in their analysis of reports about benefit sanctions that children's experiences are generally ignored and 'everyday experiences are coloured by the consequences of political decisions considered too adult for their reckoning.' (Benson and Rosen, 2017: 308). It is indeed ironic that whilst children and families (lone parents and large families in particular) are bearing the brunt of the Government's austerity measures (De Henau and Reed, 2016), with 3.9 million children living in poverty in the UK in 2014-15 (CPAG, 2016), the impact on children themselves is, by and large, being ignored by the media. As Ridge (2002:13) has shown, children are not passive beings; even in constrained circumstances they actively shape family food practices to help cope with the financial burdens that they and their families face (Knight et al, in press 2018).

Our paper demonstrates that the causes of food poverty appear to be attributed less to individual failings than to the causes of poverty more generally in print media, and this is especially evident in the more left-leaning press, such as The Guardian and The Mirror (Harkins and Lugo Ocando, 2016). We have also shown that that children's and families' experiences of food poverty are, by and large, under-represented by the UK newspaper media. For the public to receive a more realistic picture of food poverty as experienced by children and families in the UK, greater attention needs to be given to its multi-dimensional nature. This includes addressing food as a human right, acknowledging the social participatory aspects of food and eating and presenting the expressed views and experiences of the children and their families themselves. That said, if these matters are not part of the dominant public and political debates, the press is unlikely to report them, especially when journalists are highly selective in the types of research evidence they are prepared to report. After all, the UK media is an important part of national and global elites that conserve the interests of the more powerful groups in society (Jones, 2015). For progress, food poverty debates require a major shift from the normalisation and de-politicisation of emergency food aid in the form of food banks to the acknowledgement that adequate food for nutritional and social needs are directly linked to dignity, social equality and justice.

\section{Acknowledgements}

The research leading to these results has received funding from the European Research Council under the European Union's Seventh Framework Programme (FP7/2007-2013) /ERC 
grant agreement $n^{\circ} 337977$. We are very grateful to the three anonymous reviewers for helpful feedback on earlier drafts of this paper.

\section{References}

Alderson, P. (2013) Childhoods Real and Imagined. Volume 1: Introduction to Critical Realism and Childhood Studies. London: Routledge.

Alderson, P. (2016) The Missing Third that Skews Sociology. Discover Society. February $2^{\text {nd }}$. Altheide, D.L. and Schneider, C.J. (2013) Qualitative Media Analysis. $2^{\text {nd }}$ edition. Sage: London.

All Parliamentary Inquiry into Hunger in the UK (APPG) (2014) Feeding Britain. A strategy for zero hunger in England, Wales, Scotland and Northern Ireland. www.foodpovertyinquiry.org

Baillie, R. (2011) An examination of the public discourse on benefit claimants in the media. Journal of Poverty and Social Justice, vol 19 no 1 pp. 67-70.

Beattie, J. (2015) 'IDS says job advisers will be posted in food banks; Last week the PM said he didn't want anyone reliant on foodbanks. Now Iain Duncan Smith wants to station job advisers in them', The Mirror, October $28^{\text {th }}$.

Benson, L. and Rosen, R. (2017) From silence to solidarity: Locating the absent 'child voice' in the struggle against benefit sanctions. Children and Society, vol 31 pp. 302-314.Bernstein, B. (2000) Pedagogy, Symbolic Control and Identity: Theory, Research, Critique, Revised Edition. Lanham, MD: Rowman \& Littlefield.

Bickel, G, Nord, M, Price, C, Hamilton, W, Cook, J. (2000). Guide to measuring household food security revised, January 2000. U.S. Department of Agriculture, Food and Nutrition Service, Alexandria, VA; 2000. Available at http://www.fns.usda.gov/oane. (and (by linkage from) the Economic Research Service Website: http://econ.ag.gov/briefing/foodsecurity.

Bird, S. (2014) 'Unpalatable truth about food banks the left finds so hard to swallow', The Daily Mail, March $13^{\text {th }}$. 
Butler (2014). 'Food and Poverty'. Symposium: Overcoming the Disconnect: Doing and Using Food Research now and into the Future. BSA Food Study Group Conference 2014 'Food and Society'. Monday 30 June 2014. British Library Conference Centre, London: UK.

Butler, P. (2015) 'FFood bank jobcentres': will DWP make charity handouts part of welfare state? Iain Duncan Smith's move to put jobcentre staff in food banks suggests a shift in outlook - and is tacit admission of link between welfare policy and food poverty', The Guardian, October $28^{\text {th }}$.

Braun, V. and Clarke, V. (2006) Using thematic analysis in psychology. Qualitative Research in Psychology, vol 3 no 2: 77-101.

Channel 4 (2014). Dispatches: Breadline Kids. $9^{\text {th }}$ June. Available at: http://www.channel4.com/programmes/dispatches/videos/all/dispatches-breadlinekids/3603414300001

Chase, E. and Walker, R. (2015) 'Constructing reality?: The 'discursive truth' of poverty in Britain and how it frames the experience of shame' in Chase, E. and Bantebya-Kyomuheno, G. (eds) Poverty and Shame. Global Perspectives. Oxford: Oxford University Press.

Chauhan, A. and Foster, J. (2013) Representations of poverty in British newspapers: a case of 'othering' the threat? Journal of Community and Applied Social Psychology, vol 24 pp. 390405.

Child Poverty Action Group (CPAG) (2016) Child Poverty Facts and Figures. London: CPAG. http://www.cpag.org.uk/child-poverty-facts-and-figures

Cooper, N., Purcell, S. and Jackson, R. (2014). Below the Breadline. The relentless rise of food poverty in Britain. Church Action on Poverty and Oxfam. Available at: www.churchpoverty.org

De Henau, J. and Reed, H. (2016) 10 Years of austerity: the impact on low income households and women. Poverty. Issue 154. London: Child Poverty Action Group (CPAG). http://cpag.org.uk/content/10-years-austerity-impact-low-income-households-and-women

Dowler, E. (2002) Food and Poverty in Britain: Rights and Responsibilities. Social Policy and Administration, vol 36 no 6 pp. 698-717 
Dowler, E. and O'Connor, D (2012) Rights-based approaches to addressing food poverty and food insecurity in Ireland and UK. Social Science and Medicine vol 74 pp. 44-51.

Dowler, E., and Turner, S. (2001). Poverty Bites: Food, Health and Poor Families. London:, CPAG.

Dugan, E. (2014) 'Food poverty: the scandal that shames Britain; Nearly a million people now rely on handouts to eat - and benefit reforms may be to blame. 600 religious leaders combine to condemn $163 \%$ increase in food bank in past year. Public vigil outside Parliament to call for end to hunger'. The Independent, April $16^{\text {th }}$.

Garrett, P.M. (2015) Words matter: deconstructing 'welfare dependency in the UK. Critical and Radical Social Work, vol 3 no 3 pp 389-406

Garthwaite, K. (2016) Stigma, shame and 'people like us': an ethnographic study of foodbank use in the UK'. Journal of Poverty and Social Justice, vol 24 no 3 pp 277-289.

Greater London Authority (GLA) and Ipsos MORI (2013) Child Hunger in London. Understanding Food Poverty in the Capital. London:GLA

Harkins, S. and Lugo-Ocando, J. (2016) All people are equal, but some people are more equal than others'. In Servaes, J. and Oyedemi, T. (Eds.), The Praxis of Social Inequality in Media A Global Perspective. Lexington Books. Pp. 3-19.

Helm, T. (2013) 'Charities condem Iain Duncan Smith for food bank snub'. The Guardian, December $21^{\text {st. }}$

Hick, R. (2012) The capability approach: Insights for a new poverty focus, Journal of Social Policy, vol 41 no 2 pp 291-308.

Jensen, T. (2014) Welfare commonsense, poverty porn and doxosophy. Sociological Research Online, vol 19 no 3

Jones, O. (2015) The Establishment. London: Penguin Books.

Kellogg's, YouGov (2015) Isolation and Hunger: The Reality of School Holidays for Struggling Families. file:///C:/Users/abiga/Downloads/HOLIDAY+HUNGER+REPORT.pdf Knight, A., O'Connell, R. and Brannen, J. (in press, 2018) Eating with friends, family or not at all: young people's experiences of food poverty in the UK. Children and Society. Special Issue: Children's and teenagers' food practices in contexts of poverty and inequality.

Kontorravdis, E., Bloemen, O. and Crowe, B. (2016) "Living is more important than just 
surviving”. Listening to what children think about food insecurity. Children's and Young People's Commissioner, Nourish, Homestart. Scotland

http://www.nourishscotland.org/wpcontent/uploads/2016/10/Living_more_important_than_surviving.pdf

Krippendorf, K. (2013) Content Analysis. An Introduction to its Methodology. $3^{\text {rd }}$ edition. London: Sage.

Krumer-Nevo, M. and Benjamin, O. (2010) Critical Poverty Knowledge. Contesting othering and social distancing. Current Sociology, vol 58 no 5 pp 693-714.

Lister, R. (2004) Poverty. Cambridge,: Polity Press

Lambie-Mumford, H., Crossley, D., Jensen, E., Verbeke, M. and Dowler, E. (2014).

Household Food Security in the UK: A Review of Food Aid. Commissioned by Defra. University of Warwick and Food Ethics Council.

Lambie-Mumford, H. and Green, M.A. (2017) Austerity, welfare reform and the rising use of food banks by children in England and Wales. Area vol 49 no 3 pp 273-279.

Lambie-Mumford, J. and O'Connell, R. (2015). Food, poverty and policy: evidence base and knowledge gaps. Report of the BSA Food Study Group-SPERI event. 30th June 2015 Available at http://speri.dept.shef.ac.uk/wp-content/uploads/2015/09/Food-poverty-policyevent-report.pdf

Machin, R.J. (2016) Understanding holiday hunger. Journal of Poverty and Social Justice vol 24 no 3 pp 311-19.

Mayall, S. (2014) 'Britain's breadline kids: Up to 5 million children will be living in poverty by 2020; new research by Oxfam revealed the true extent of the amount of British children living in poverty, with families taking drastic measures', The Mirror, June $8^{\text {th }}$.

McEnhill, L. and Byrne, V. (2014) 'Beat the Cheat': portrayals of disability benefit claimants in the print media. Journal of Poverty and Social Justice vol 22 no 2 pp 99-110

McKendrick, J.H., Cunningham-Burley, S and Backett-Milburn, K. (2003) Life in Low Income Families in Scotland. Edinburgh, University of Edinburgh for Scottish Executive. 
McKendrick, J.H., Sinclair, S., Irwin, A., O’Donnell, H., Scott, G. and Dobbie, L. (2008) The Media, Poverty and Public Opinion in the UK. York: Joseph Rowntree Foundation.

Owen and Sharma, N. (2004) Food poverty in the school holidays. South West: Barnardos

Patrick, R. (2016) Living with and responding to the 'scrounger' narrative in the UK: exploring everyday strategies of acceptance, resistance and deflection. Journal of Poverty and Social Justice vol 24 no 3 pp 245-59

Pember Reeves, M (1913) Round About a Pound a Week. London: Virago.Purdam, K., Garratt, E. and Esmail, A. (2015) Hungry? Food insecurity, social stigma and embarrassment in the UK. Sociology vol 50 no 6 pp1072-1088.

Rayner, J. (2015) 'How Kids Company feeds Britain's hungry children;' The Observer, February $16^{\text {th. }}$

Riches, G. and Silvasti, T. (eds) (2014) First World Hunger Revisited. Food Charity or the Right to Food? London: Palgrave Macmillan.

Ridge, T. (2002) Childhood Poverty and Social Exclusion: From a Child's Perspective. Bristol: Policy Press.

Ridge, T. (2009) Living with poverty. A review of the literature on children's and families' experiences of poverty. London, Report for the Department for Work and Pensions. Research report Number 594.

Ridge, T. (2013) 'We are all in this together?' The hidden costs of poverty, recession and austerity policies on Britain's poorest children. Children and Society, vol 27 pp 406-417.

Riessman, C.K. (2008) Narrative Methods for the Human Sciences. London: Sage Publications Ltd.

Styles, R. (2014) ' 'It's been hard but I want a better life for myself'. Meet the inspiring teen who lives on $£ 1.20$ a day but is determined to pursue he dream of becoming an artist', MailOnline, June $10^{\text {th }}$.

Thurman, N. and Fletcher, R. (2017): Has Digital Distribution Rejuvenated Readership?, Journalism Studies. DOI: 10.1080/1461670X.2017.1397532

Townsend, P. (1979), Poverty in the United Kingdom, London: Penguin. 
Wells, R. and Caraher, M. (2014) UK print media coverage of the food bank phenomenon: from food welfare to food charity? British Food Journal, vol 116 no 9 pp1426-1445.

Wells, R, and Caraher, M, (2016) 'Britain's Hidden Hungry? The Portrayal of Food Bank Users in the U.K. National Press'. In Servaes, J. and Oyedemi, T. (Eds.), The Praxis of Social Inequality in Media A Global Perspective. Lexington Books, pp 39-60

Williams, Z, (2014a) 'Comment: Parading hungry kids makes for good TV but bad policy: By focusing solely on children, Breadline Kids blinds us to the need for a wider solution to economic hardship', The Guardian, June $11^{\text {th }}$.

Williams, Z, (2014b) 'As children starve, where's the state?' The Guardian, December $9^{\text {th }}$ Wring, D, and Ward, S. (2010) The media and the 2010 campaign: The Television election. Parliamentary Affairs, vol 63 no 4 pp 802-817.

Wright, O. (2014) Tory attitudes to poverty under fire over benefit sanctions and Baroness Jenkin comment that poor 'don't know how to cook'; Baroness Jenkin forced to apologise after blaming food bank use on culinary incompetence. The Independent, December $8^{\text {th }}$. Wynne Jones, R. (2014a) 'Anti-poverty campaigners deliver a timely Budget message to George Osborne; The Mirror's Real Britain columnist joins campaigners and faith leaders to deliver a petition to the Chancellor a day before his decisions could cost more lives', The Mirror, March $18^{\text {th }}$.

Wynne Jones, R. (2014b) 'Families are slipping through the welfare net into hunger and poverty; On Monday night's Dispatches documentary, Breadline Kids, 10 year old Cara described how it feels to be hungry in Britain in 2014. Wise beyond her years, she explained there's no point being angry because it just makes the hunger worse', The Mirror, June $10^{\text {th }}$. Wynne Jones, R. (2015) 'The kids forced to live on margarine butties in foodbank Britain during school holidays; Thousands of families who rely on free school lunches and breakfasts are turning to foodbanks in the summer to give their children a decent meal', The Mirror, August $19^{\text {th }}$. 


\begin{abstract}
' In in the UK there is currently no accepted definition of food poverty or insecurity and the terminology is 'emergent' (Lambie-Mumford and O'Connell, 2015). Although some definitions of food poverty recognise food as an important means of social participation, the construct captured by validated measures of food insecurity such as those used in the USA, Canada and Australia, often do not include social acceptability of food procurement or food's role in social participation (e.g. Bickel et al., 2000).
\end{abstract}

ii Clear a Plate is a campaign by Oxfam and Unilever to prevent food waste 
How do children and their families experience food poverty according to UK newspaper media 2006-20015?

Figure 1 Inclusion and exclusion criteria

\begin{tabular}{|c|c|}
\hline Inclusion Criteria & Exclusion Criteria \\
\hline $\begin{array}{ll}\checkmark & \text { National edition of the newspaper } \\
\checkmark & \text { UK focus } \\
\checkmark & \text { Article is about food poverty within } \\
& \text { a family context } \\
\checkmark & \text { Sunday edition of Web-based } \\
& \text { edition }\end{array}$ & $\begin{array}{l}\times \text { Regional newspaper - e.g. Ireland or } \\
\text { Scotland focused } \\
\times \text { Global focus }- \text { unless clear } \\
\text { comparison with the UK } \\
\times \text { Focus is on another country } \\
\times \text { Letters } \\
\times \text { Monthly/Weekly/Daily news round } \\
\text { ups or summaries } \\
\times \text { TV listings } \\
\times \text { Book or restaurant reviews } \\
\times \text { Live reports - e.g. reporting on } \\
\text { political conference } \\
\times \text { 'Food poverty' only mentioned as a } \\
\text { side comment and not related to the } \\
\text { article as a whole }- \text { e.g. stating that } \\
\text { the person in question campaigned } \\
\text { in this area but the article about } \\
\text { something else. }\end{array}$ \\
\hline
\end{tabular}


Figure 2: Number of articles both relevant and non-relevant to food poverty in the context of children or family in the UK $2006-2015$

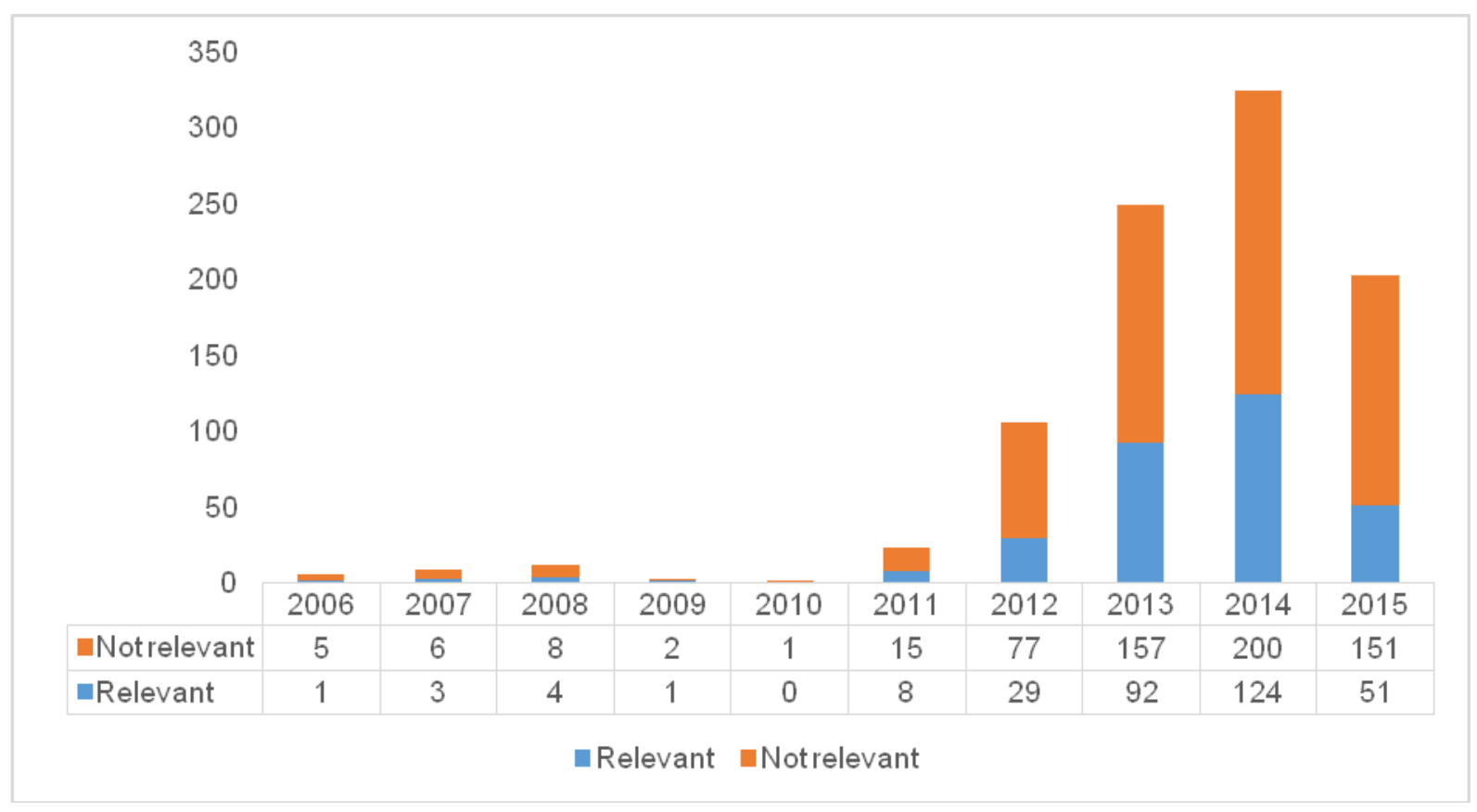

Figure 3: Total number of relevant articles over time $2006-2015$

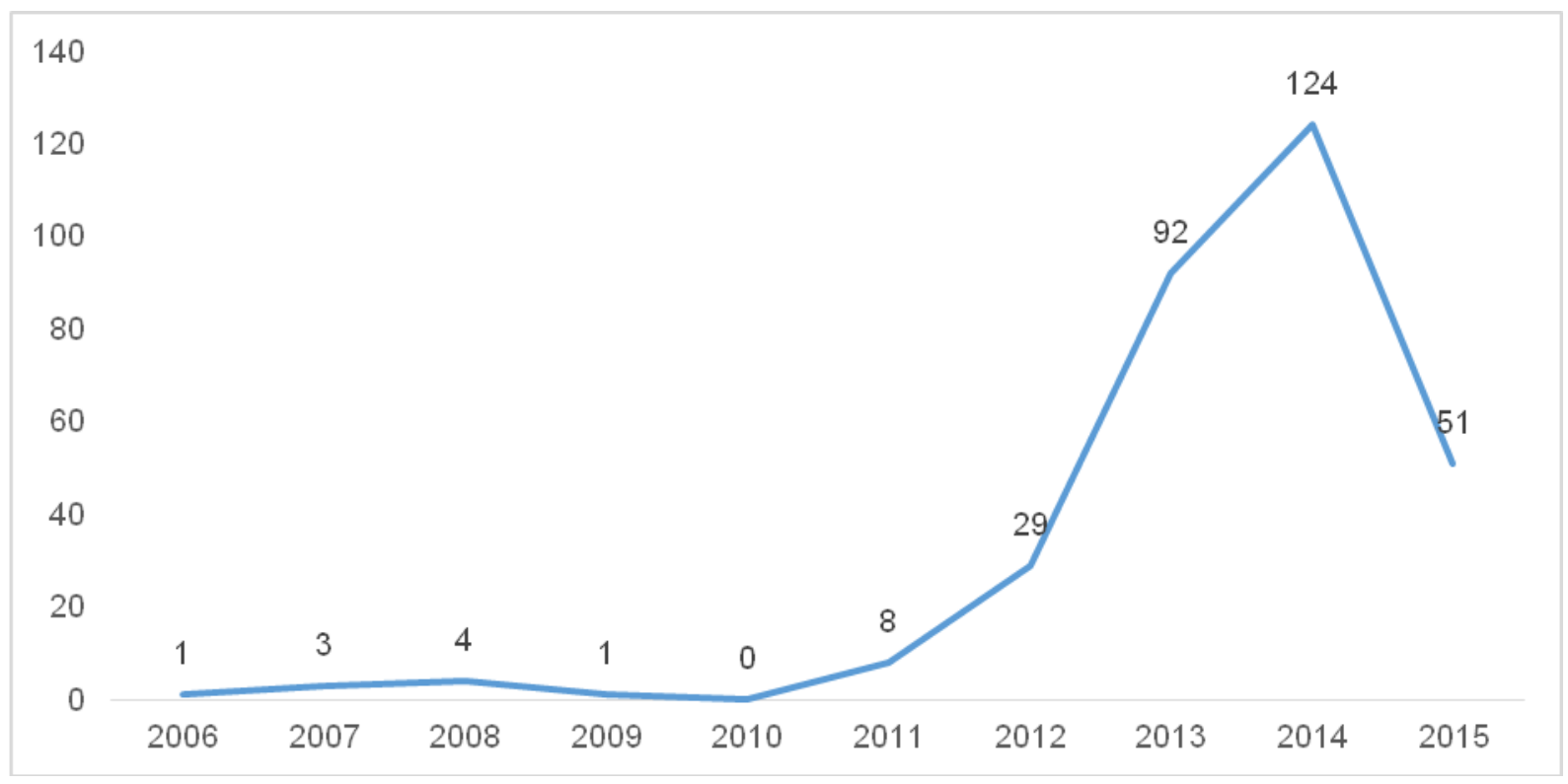


Figure 4: Total number of relevant articles for analysis by newspaper title $2006-2015$

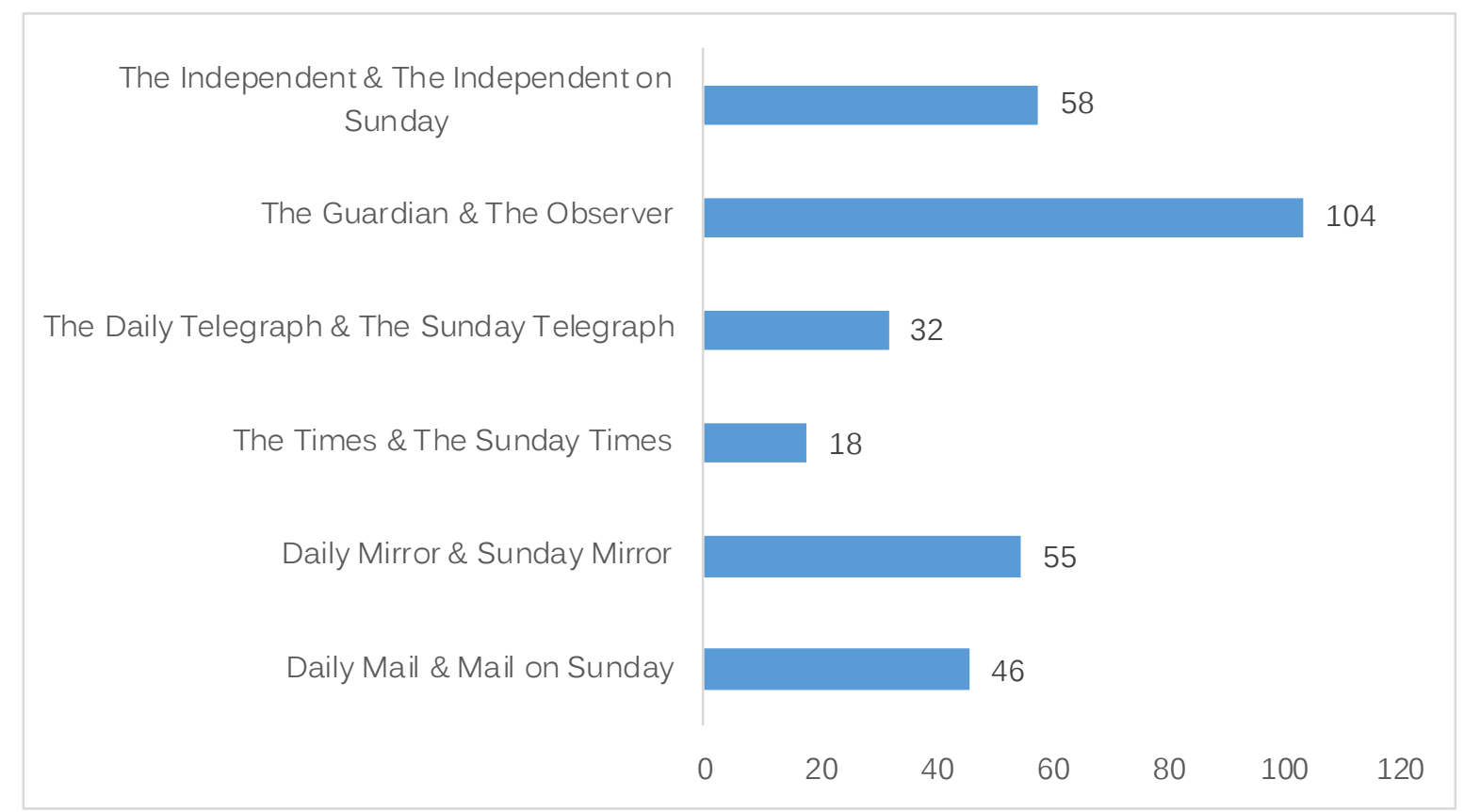

Figure 5: Contrasting articles about food banks

\begin{tabular}{|l|l|l|}
\hline Newspaper & $\begin{array}{l}\text { Date and } \\
\text { author }\end{array}$ & Headline \\
\hline Daily Mail & $\begin{array}{l}\text { Steve Bird } \\
\text { March 13 } \\
2014\end{array}$ & $\begin{array}{l}\text { 'Unpalatable truth about food banks the left finds so } \\
\text { hard to swallow' }\end{array}$ \\
\hline Daily Mirror & $\begin{array}{l}\text { Ros Wynne } \\
\text { Jones } \\
\text { March } 18^{\text {th }}\end{array}$ & $\begin{array}{l}\text { 'Anti-poverty campaigners deliver a timely Budget } \\
\text { message to George Osborne; The Mirror's Real Britain } \\
\text { columnist joins campaigners and faith leaders to deliver } \\
\text { a petition to the Chancellor a day before his decisions } \\
\text { could cost more lives' }\end{array}$ \\
\hline
\end{tabular}


Figure 6: Contrasting articles about children's experiences of food poverty

\begin{tabular}{|l|l|l|}
\hline Newspaper & $\begin{array}{l}\text { Date and } \\
\text { author }\end{array}$ & Headline \\
\hline The Mirror & $\begin{array}{l}\text { Ros Wynne } \\
\text { Jones } \\
\text { June } 10^{\text {th }} 2014 \mathrm{~b}\end{array}$ & $\begin{array}{l}\text { 'Families are slipping through the welfare net into } \\
\text { hunger and poverty; On Monday night's Dispatches } \\
\text { documentary, Breadline Kids, 10-year-old Cara } \\
\text { described how it feels to be hungry in Britain in } 2014 . \\
\text { Wise beyond her years, she explained there's no point } \\
\text { being angry because it just makes the hunger worse' }\end{array}$ \\
\hline MailOnline & $\begin{array}{l}\text { Ruth Styles } 10^{\text {th }} 2014 \\
\text { ''It's been hard but I want a better life for myself'. } \\
\text { Meet the inspiring teen who lives on } £ 1.20 \text { a day but is } \\
\text { determined to pursue he dream of becoming an artist', }\end{array}$ \\
\hline
\end{tabular}

